SHS Web of Conferences 2, 00031 (2012)

DOI: $10.1051 /$ shsconf $/ 20120200031$

(C) Owned by the authors, published by EDP Sciences, 2012

\title{
Implementation of the higher education accessibility principle in Latvia: Current situation and its development possibilities
}

\author{
A. Stankevics and I.J. Mihailovs \\ Rīga Stradiņš University / Daugavpils University
}

\begin{abstract}
Accessibility of higher education system is an important term of higher education development, providing equity rights and possibilities to study for each person. Therefore the understanding of accessibility is important issue for each state higher education policy. The understanding of higher education accessibility in Latvia is discussed in the topic, analyzing this term in comparison with situation in other states, identifying the most important aspects of higher education accessibility and marking the problems connected with the accessibility in Latvia.
\end{abstract}

Key words: accessibility, higher education, development of higher education system

The functioning and development of higher education, just as any other social system, depend on its accessibility. Namely, the more accessible qualitative higher education studies/higher education overall environment are, the more human and other resources "flow in" higher education, thus providing the competitiveness of higher education itself, its return, efficiency and sustainability.

The higher education accessibility principle nowadays is connected with persons' equity, as well as rights to choose and study in the appropriate higher education studies' program. As it has been emphasized by the Latvian sociologist O. Pavlovs, the topicality of education accessibility problems cannot be denied, especially regarding the equity of persons' rights to learn/study. With reference to the outstanding sociologist E. Dirkem, he accentuates the fact that absolute equity is impossible, however it is necessary to provide "the equity of possibilities at the start", i.e., enrolment, which does not exclude the support to talented students, as well as provides support for other specially protected groups (Pavlovs, 2002; 75-76), as well as equal attitude and fair competition conditions during the study time. In this respect it should be pointed out that the $3^{\text {rd }}$ article first part of the Education Law of the Republic of Latvia (Izglìtîbas likums) defines that "any person has rights to obtain education regardless of one's property and social status, race, nationality, ethnic affiliation, gender, religious and political affiliation, health condition, occupation and place of residence." But the $46^{\text {th }}$ article third and fourth part of the Law of Higher Education determine that all the higher educational establishments are obliged to enrol students in the "open and equal competition". Moreover, higher educational establishments "can determine additional requirements regarding special previous education, particular suitability and qualification or fulfilment of other requirements only after receiving confirmation from the Higher Education Council" (Augstskolu likums).

Therefore, fair education accessibility is characterized by diminishing the dependence of education obtaining on person's origin, gender, social group and income, in this way maximizing the dependence of higher education obtaining on abilities, results and knowledge of a person. The Latvian researcher of higher education R. Kaša defines accessibility of higher education as a status "when equivalently qualified students have equal possibilities to study in a higher educational establishment regardless of their social and economic conditions" (Kaša, 2009; 83-100).

However, accessibility of higher education is more associated with ideal, which has not yet been achieved in any country of the world but which must be aspired for. Consequently, it is necessary in any

This is an Open Access article distributed under the terms of the Creative Commons Attribution License 2.0, which permits unrestricted use, distribution, and reproduction in any medium, provided the original work is properly cited. 


\section{SHS Web of Conferences}

country to ensure not only implementation of the higher education accessibility but also perform regular monitoring (measurement) of the higher education accessibility and analysis of the obtained data, as well as develop appropriate policy of higher education considering the research results, which by all means diminishes inequity among different groups in accessibility / obtaining higher education.

It should be pointed out that although higher education researches are widespread in the world (Otero, McCoshan; Scott), in Latvia this theme still remains forgotten in scope of higher education management and policy studies (as an exception should be regarded those separate cases, when students of different study levels in their final works focused on the problems of the higher education accessibility), except some publications of E. Kaša (Kaša, 2003; Kaša, 2004; Kaša, 2009), thus this important issue is being only fragmentary considered in the higher education policy planning and implementation process. Therefore, the aim of this article is to fill gaps partly by analyzing the current situation of the implementation of the higher education accessibility principle in Latvia and its development (improvement) possibilities.

\section{Materials and methods}

In the research the following methods were used: analysis of the scientific literature sources and analysis of normative documentation.

\section{Results}

It is necessary to admit that the higher education accessibility (as ability to use / consume higher education services) concept is closely connected with / directly subordinated to three other significant higher education functioning, development and sustainability concepts: education quality, economic efficiency of education and financing of education (Global Higher Education Rankings Affordability and Accessibility in Comparative Perspective; Šņitnikovs; Zemīte, 2009; Зарицкий, 2006), which forms a particular circle of dependence, where changes in one sector of the circle, for example, education quality, directly affect the functioning of other sectors.

Consequently, if the content of any of the four concepts is being administratively changed, for example, by inventing a new regulation or by changing the ordinary form of higher education action, then it will irreversibly affect the content of other concepts. Thus, by increasing the volume of the higher education financing the number of so-called budget places will increase, the increase will be observed also in amount of resources for research work, improvement of studies' content and quality, co-operation projects, etc.

It is evident that the higher education accessibly in the Republic of Latvia has significantly increased after the regaining of impendence, which has resulted in the formation of higher education market, considerable increase of higher education establishments in the country, developing of the system of private higher education establishments, as well as developing of the pay studies supply, increase of higher education prestige and its significance in society / at work etc. Yet to perform a general analysis of the implementation of the higher education accessibility principle, it is necessary to consider several basic elements of the higher education accessibility:

1) Organizational or institutional accessibility of higher education - an aggregate of institutional and materially technical conditions, which ensure the existence of higher educational establishments, as well as their functioning and further activities and enable them to offer their services to the interested persons - study candidates (Сухочёв).

2) The financial affordability of higher education - an aggregate of financial resources, which is assigned to higher education, enabling them to offer study candidates pay, free of charge or partly pay (budget) higher education studies, as well as those resources, which a study candidate can / is legal to receive to study in a higher educational establishment and pay the costs of higher education studies (vouchers, studies' and student's credits, etc.). The financial affordability of higher education is possible 


\section{Int. Conf. SOCIETY. HEALTH. WELFARE; Congr. of Rehabilitation Doctors of Latvia}

when the population has reached a particular level of purchasing ability, which enables the population to pay not only the study fee but also other costs connected with higher education studies and satisfy their daily needs (Сухочёв; Менг). Thus higher education financial affordability is connected with higher education socially financial accessibility - an aggregate of conditions enabling a person to take decision to study in a higher educational establishment, and in case of lack of personal financial resources to be able to receive financial resources for higher education studies on preferential conditions (usually in the form of preferential loan), accordingly providing a possibility to study according to a person's choice and providing that the person's social and financial situation is not essentially affected. Although every full time (regular) student has a possibility to obtain both student's and studies' credit (however, the issue of credit guarantor is still controversial), the one can admit with good reason that the system of students' social protection and support is comparatively poorly developed (especially accessibility of the student's credit to part-time students). This is the reason why in the current difficult socially economic conditions the higher educational establishments have put efforts to expand social support possibilities for students - children-care services, free of charge dormitories, short term loans, and in form of other services.

3) Juridical or legal accessibility of higher education - an aggregate of normative regulations, which assigns / guaranties the rights to study in a higher educational establishment to all groups of population, legally providing equal possibilities for the population to study, as well as eliminating the chance of discrimination among the study candidates (for example, against gender, age, origin, sexual orientation, political opinion, health condition, social group, etc.).

4) Physical, also territorial or geographical accessibility of higher education - connected with the location of higher educational establishments' network (for example, in Latvia higher educational establishments are basically located / concentrated in the capital city Riga, however, outside Riga there are 14 higher educational establishments and there is a wide network of higher educational establishments' affiliates, which offer higher education services as close as possible to the place of residence). It is possible to analyze higher educational establishments' accessibility to different groups (for example, for persons with special needs) and e-studies and distance learning supply alongside with the evaluation of physical accessibility of higher education.

5) Intellectual (regarding the content and methodology) accessibility of higher education compliance of the higher education content and quality to the previous knowledge and skills (level of education) of a particular group (basically graduates of the secondary schools), as well as abilities, ensuring the consistency of the learning / study process, regularity and continuity (succession), as well as appropriate methodological and informative organization of higher education studies' process.

Alongside with the recognizing the crucial importance of the higher education accessibility principle in the functioning of the higher education system, the rankings of the higher education accessibility (measuring involvement of the youth's specific rate in higher education, level of the higher education among youth, gender parity among the youth and social equality of rights (see Table 1) are formed in several countries of the world. The highest level of the higher education accessibility has been reached by the Netherlands, Finland and Great Britain (Global Higher Education Rankings Affordability and Accessibility in Comparative Perspective; Карпенко, Бершадская).

However, the analysis of the development of Latvia higher education system in the last 20 years gives evidence that the level of higher education accessibility has comparatively grown and is above the average (in comparison with other European countries). In Latvia optimal institutional, intellectual and legal level of higher education accessibility is achieved at present. In the last 7 years also the supply and financing (number of budget places) of regional higher educational establishments has remarkably increased, which significantly expands the accessibility of higher education in the regions, diminishing the former heterogeneous supply of higher education. Yet the quality of studies and their compliance with global, national and regional development priorities is still a controversial issue, as well as compliance of the offered higher education studies' programs with the wishes and abilities 


\section{SHS Web of Conferences}

Table 1. Indicators characterizing the higher education accessibility.

\begin{tabular}{|c|c|c|}
\hline Indicator & Characterization & $\begin{array}{l}\text { Coefficient of } \\
\text { the indicator's } \\
\text { relevance }(\%)\end{array}$ \\
\hline $\begin{array}{l}\text { 1. Involvement of youth } \\
\text { in higher education }\end{array}$ & $\begin{array}{l}\text { Regarding the fact that in different } \\
\text { countries the age of students ranges } \\
\text { in the age group from } 18 \text { to } 24 \text {, the } \\
\text { percentage of possibly wider age group } \\
\text { is considered (the age group is chosen } \\
\text { inside the country) }\end{array}$ & 25 \\
\hline $\begin{array}{l}\text { 2. Level of education } \\
\text { reached by youth }\end{array}$ & $\begin{array}{l}\text { Pro rata of population in the age group } \\
\text { from } 25 \text { to } 34 \text { who have graduated } \\
\text { programs of the higher educational } \\
\text { establishments } \%\end{array}$ & 25 \\
\hline $\begin{array}{l}\text { 3. The educational } \\
\text { equity index }\end{array}$ & $\begin{array}{l}\text { It reflects the compliance of the } \\
\text { students' and existing population stru- } \\
\text { cture to the socially-economic status } \\
\text { (males in the age group from } 45 \text { to } \\
65 \text { with higher education percentage } \\
\text { compliance with higher educational } \\
\text { establishment's students' percentage, } \\
\text { whose fathers have higher education). } \\
\text { High EEI indicators testify the compli- } \\
\text { ance of the students to the average level } \\
\text { of society but low indicators testify } \\
\text { that the majority of the youth entering } \\
\text { higher educational establishments } \\
\text { come from privileged families. }\end{array}$ & 40 \\
\hline $\begin{array}{l}\text { 4. The gender equity } \\
\text { index }\end{array}$ & $\begin{array}{l}\text { It testifies the proportion of male } \\
\text { and female gender students, which is } \\
\text { calculated basing on gross number of } \\
\text { students' enrolment. }\end{array}$ & 10 \\
\hline
\end{tabular}

of the studies' candidates (i.e., for example, wish to study social sciences in opposition to constantly increasing national support to natural science studies) (Latvija. Pārskats par tautas attīstību 2004/2005: Rīcỉbspēja reǵionos, 2005; 57-66).

\section{Conclusions}

Despite the wide range of higher education services, the present condition in Latvia regarding youth with higher education (approximately $28 \%$ of population in the age group from 30-34) must be assessed as unsatisfactory. Therefore, one of the EU and accordingly Latvia's further development aims is until 2020 to achieve the condition when the number of persons with higher education reaches $40 \%$ from the appropriate group of population (Eiropa 2020. Stratēgija gudrai, ilgtspējīgai un integrējošai izaugsmei). However, already the present forecasts indicate that till 2020 in Latvia this specific rate can increase only for $8 \%$, accordingly reaching 36\% (T. Koķe piedalās ES Izglīî̉bas, jaunatnes lietu un kultūras ministru padomes sanāksmē; Izglītības stratēgija Latvijā) and causing the need to solve other problems connected with the functioning of the higher education system, for example, diminishing the large specific weight 
Int. Conf. SOCIETY. HEALTH. WELFARE; Congr. of Rehabilitation Doctors of Latvia

of dropouts (approximately every fifth student drops out without finishing his/her higher education studies) (Kļāvis, 2009).

Same attention deserves the fact that at present in Latvia there is lack of researches devoted to social equity problems in the context of the higher education accessibility, which becomes especially topical in socially and economically unfavourable conditions. Thus the Ministry of Education and Science should in the nearest time allocate resources for the regular monitoring and assessment of the results regarding the higher education accessibility, for example by delegating this objective to some of the higher education quality / education supervision institutions.

Considering the present unfavourable socially economic conditions, as well as plentiful possibilities to obtain free of charge / partly pay higher education abroad, the financial affordability of Latvia higher education becomes problematic (moreover, currently free of charge higher education obtaining is basically offered only at the state owned higher educational institutions), which includes not only the study fee but also other charges connected with obtaining of higher education. The aggregate of the mentioned conditions requires immediate reorganization of functioning of the Latvia higher education system.

Therefore, one of the challenges for the development of the national higher education system becomes the necessity to improve the system of the higher education financing and the system of the students' social support, which will serve as a guarantee for the development and accessibility of higher education, int. al. the increase of socially financial affordability.

\section{References}

[1] Latvija. Pārskats par tautas attīstību 2004/2005: Rīcībspēja reǵionos (2005) [Latvia. Human development report 2004/2005: Human Capability in Regions]. Rīga: ANO Attīstības programma, LU Sociālo un politisko pētījumu institūts.

[2] Pavlovs, O. (2002) Izglītības filozofija. [Philosophy of education]. Rīga: Latvijas Akmeolog̣ijas akadēmija.

[3] Scott, P. Access in Higher Education in Europe and North America: Trends and Developments. http://www.cepes.ro/forum/pdf/Scott_access.pdf

[4] Souto-Otero, M., McCoshan, A. Study on access to education and training. Final report to the European Commission. http://ec.europa.eu/education/pdf/doc270_en.pdf

[5] Kaša, R. (2009) Augstākās izglītības pieejamība Latvijā: valsts un pašvaldību loma studentu finansēšanā [Higher education accessibility in Latvia: state and self govermnet role in the fundion of students]. Latvija 2020. Nākotnes izaicinājumi sabiedrībai un valstij. Rīga: LU akadēmiskais apgāds.

[6] Kaša, R. (2004) Kā pārvarēt plaisu, kas šķir maznodrošinātus jauniešus no augstskolas [How to manage gap, which devote poor Youth form higher educational establishment]. Izglītības reformas Latvijas sabiedrības integrācijai un labklājūbas. Pārskats par izglītību. 2003./2004. Rīga: Providus.

[7] Kaša, R. (2002) Studentu finansēšana un augstākās izglītības pieejamību Latvijā [Student funding and higher education accessibility in Latvia]. Pārmaingas Latvijas izglītībāa: izaicinājums sistèmas vadībai. Pārskats par izglītību. 2001./2002. Rīga: Providus.

[8] Izglītības stratēgéija Latvijā (2010) [Strategy of education in Latvia]. Skolotājs, 2010, Nr. 1 (79).

[9] Kļāvis, A. (2009) 22 tūkstoši studentu bez grāda un augstskolas diploma (22 thousand students without diploma and degree]. Latvijas Vēstnesis, 2009, 28. jūlijs.

[10] Šņitnikovs, A. Vai augstākā izglīīiba Latvijā ir ekonomiski efektīva? [Is Latvian higher education economically effective]. http://www.politika.lv/temas/pilsoniska_sabiedriba/6039/

[11] Zemīte, V. (2009) Pārdomas par augstāko izglītību Latvijā (Some thoughts about higher education in Latvia]. Latvijas Vèstnesis, 2009, 1. decembris. 


\section{SHS Web of Conferences}

[12] Зарицкий, Т. (2006) Культурный капитал и доступность высшего образования (порезультатам сравнительного исследования опросов московских и варшавских студентов вузов [Cultural саpital and accessibility of higher education (the results of comparative research of Moscow and Warsaw students]. Вестник общественного мнения Nr. 2.

[13] Карпенко, О., Бершадская, М. Рейтинг стран по доступности высшего образования [Accessibility of higher education rank of the states]. http://demoscope.ru/weekly/ 2009/0375/ analit03.php

[14] Менг, А. Формирование социально-экономической доступности высшего профессионального образования [Formation of social-economic accessibility of higher vocational education]. http://izvestia.isea.ru/pdf.asp?id=4111

[15] Сухочёв, В. Организационная доступность высшего образорания [Organizational accessibility of higher education]. http://sun.tsu.ru/mminfo/000063105/316/image/316-138.pdf

[16] Сухочёв, В. (2009) Финансовая доступность высшего образования [Financial affordability of higher education]. Экономика и управление, Nr. 1.

[17] Augstskolu likums [Law of Higher Education]. http://www.likumi.lv/doc.php?id=37967

[18] Eiropa 2020. Stratēǵija gudrai, ilgtspējīgai un integrējošai izaugsmei [Europe 2020. A European strategy for smart, sustainable and inclusive grow]. http://ec.europa.eu/eu2020/ pdf/ 1_LV_ACT_part1_v1.pdf

[19] Global Higher Education Rankings Affordability and Accessibility in Comparative Perspective. http://www.educationalpolicy.org/pdf/global2005.pdf

[20] Izglīīibas likums [Educational Law]. http://www.likumi.lv/doc.php?id=50759

[21] T.Koķe piedalās ES Izglītības, jaunatnes lietu un kultūras ministru padomes sanāksmē [T.Kokse take part in EU Education, Youth and culture ministers council meeting]. http://www.esia.gov.lv/lat/jaunumi/?doc=2191 